\title{
PENGARUH PENGELOLAAN KEUANGAN DAERAH DAN SISTEM AKUNTANSI KEUANGAN DAERAH TERHADAP KINERJA PEMERINTAH DAERAH (Studi Empiris Pada Organisasi Perangkat Daerah Kota Jayapura)
}

\author{
Stevani Veronica M. Ireeuw ${ }^{1}$ \\ mijehryyireeuw@gmail.com \\ Dr. Paulus K. Allo Layuk, SE., M.Si., Ak., $\mathrm{CA}^{2}$ \\ Andika Rante, SE., M.SA ${ }^{3}$ \\ Jurusan Akuntansi, Fakultas Ekonomi dan Bisnis Universitas Cenderawasih
}

\begin{abstract}
This study aims to determine: (1) The effect of financial management on the performance of local government, as well as (2) The effect of the financial accounting system on the performance of local government areas. This type of research is causative with the population were all working units (OPD) at Jayapura City, using 34 samples obtained with different educational backgrounds. The data collection method was used a questionnaire. By using multiple regression analysis tool such as SPSS version 16. The result shows that: (1) financial management has a negative significant effect on the performance of local government, and (2) financial accounting system area has positive significant effect on the performance of local governments.
\end{abstract}

Keyword : : financial management, financial accounting systems, local government performance.

\section{PENDAHULUAN}

Pengelolaan keuangan menurut (PP Nomor 58, 2005) adalah keseluruhan kegiatan yang meliputi perencanaan,pelaporan,pertanggungjawaban dan pengawasan keuangan daerah.Untuk melihat baik tidaknya pengelolaan keuangan daerah suatu pemerintahan dapat dilihat dari hasil Laporan Hasil Pemerikasaan (LHP) Badan Pemeriksaan Keuangan (BPK) Republik Indonesia.

Sejak diberlakukannya Undang-Undang No 12 Tahun 2008 tentang Pemerintah Daerah, telah terjadi pelimpahan wewenang yang semakin luas kepada pemerintah daerah dalam rangka meningkatkan efisiensi dan efektivitas penyelenggaraan fungsi pemerintah daerah berkaitan dengan pengelolaan keuangan daerah sebagai upaya peningkatan kinerja pemerintah daerah. Pemerintah daerah sekarang ini dihadapkan oleh banyaknya tuntutan baik dari segi internal yaitu peningkatan kinerja yang optimal dan segi eksternal yaitu adanya tuntutan masyarakat yang menghendaki, agar pemerintah daerah mampu menciptakan tujuan masyarakat daerah yang sejahtera sebagai suatu implikasi dari penerapan otonomi daerah yang mengedapnkan akuntabilitas kinerja dan peningkatan pelayanan public (Abdul :2007).

Kinerja telah menjadi salah satu kata kunci yang banyak dibicarakan berbagai organisasi mulai dari perusahaan hingga pemerintah bahkan pula perguruan tinggi.Demikian juga kinerja masuk dakam setiap aspek ekonomi kemasyarakatan.kondisi ini terlihat dari banyaknya organisasi yang memasukkn kinerja dalam visi dan misinya.Pencapaian kinerja tidak hanya diharapkan pada

\footnotetext{
${ }^{1}$ Alumni Jurusan Akuntansi FEB Uncen

${ }^{2}$ Dosen Jurusan Akuntansi FEB Uncen

3 Dosen Jurusan Akuntansi FEB Uncen
} 
karyawan saja melainkan dalam jangka panjang diharapkan mampu meningkatkan kinerja kelembagaan (Ratna \& dkk, 2016).

Faktor lainnya yang juga dapat mempengaruhi kinerja pemerintah adalah sistem akuntansi keuangan daerah. Pengertian dari Sistem akuntansi keuangan daerah adalah proses pengidentifikasian, pengukuran, pencatatan, dan pelaporan transaksi ekonomi (keuangan) dari entitas pemerintah daerah (kabupaten, kota, atau provinsi) yang dijadikan sebagai informasi dalam rangka pengambilan keputusan ekonomi yang diperlukan oleh pihak-pihak eksternal entitas-entitas pemerintah daerah (kabupaten, kota, atau provinsi).

Data Sistem akuntansi keuangan daerah yang dilaksanakan secara efektif dan efisien sangatlah penting untuk menghindari adanya penyimpangan dan penyelewengan yang terjadi. Oleh karena itu, para pengguna anggaran harus mengetahui dengan baik siklus pencatatan yang ada pada sistem akuntansi keuangan daerah yang menggambarkan setiap tahapan dalam proses yang dilakukan. akuntansi yang dilaporkan dalam Sistem Akuntansi Keuangan Daerah, dikaitkan dengan data nonfinansial seperti data statistik memungkinkan instansi pemerintah untuk menilai efisiensi, sejauh mana sumber daya yang ada telah dimanfaatkan secara ekonomis dan penilaian efektivitas suatu instansi tersebut mampu memberikan pelayanan maksimum kepada masyarakat dengan sumber yang tersedia, termasuk menilai apakah hasil suatu program dapat mencapai konsekuensi-konsekuensi yang dituju.

Alasan penelitian ini dilakukan adalah untuk melihat: 1). Apakah pengelolaan keuangan daerah berpengaruh terhadap kinerja pemerintah daerah pada Organisasi Perangkat Daerah di Kota Jayapura ? dan 2). Apakah system akuntansi keuangan daerah berpengaruh terhadap kinerja pemerintah derah pada Organisasi Perangkat Daerah di Kota Jayapura ?. Dengan tujuan; 1) Untuk menguji dan mengetahuai pengaruh pengelolaan keuangan derah terhadap kinerja pemerintah daerah. 2). Untuk menguji dan mengetahui pengaruh system akuntansi keuangan daerah terhadap kinerja pemerintah daerah.

\section{TINJAUAN PUSTAKA}

\subsection{Teori Keagenan}

Teori keagenan merupakan perjanjian antara satu atau lebih prinsipal dengan agen implementasi dari teori keagenan berupa perjanjian yang berisi proporsi hak dan kewajiban masingmasing pihak (Jensen \& Meckling, 1976).Namun,dalam prakteknya terdapat kepentingan yang berbeda antara prinsipal dan agen sehingga menimbulkan konfil kepentingan atau agency problem.Untuk meminimumkan konflik tersebut prinsipal dan agen sepakat untuk menjembatani konflik tersebut dengan pihak ketiga dengan menggunakan auditor (Yuliana Dwi Jayanti, 2015).

Berkaitan dengan masalah keagenan,praktek pelaporan keuangan dalam akuntansi sektor publik merupakan suatu konsep yang didasari oleh teori keagenan.Dalam pengelolaan keuangan daerah,pemerintah yang bertindak sebagai agen mempunyai kewajiban menyajikan informasi yang bermanfaat bagi para pengguna informasi keuangan pemerintah yang bertindak sebagain prinsipal dalam menilai akuntabilitas dan membuat keputusan baik keputusan ekonomi,sosial maupun politik.

Teori ini digunakan untuk menjelaskan adanya hubungan antara rakyat sebagai prinsipal dan pemerinth sebagai agen. Pemerintah sebagai kewajiban pihak pemegang amanah (agen) untuk memberikan pertanggungjawaban, menyajikan, melaporkan dan mengungkapkan segala aktivitas dan kegiatan yang menjadi tanggung jawabnya kepada rakyat selaku pihak pemberi amanah (prinsipal) yang memiliki hak untuk meminta pertanggungjawaban tersebut. 


\subsection{Kinerja Pemerintah Daerah}

Menurut Chabib (2011:3) kinerja adalah gambaran tingkat pencapaian pelaksanaan suatu kegiatan/ program/ kebijakan dalam mewujudkan sasaran, tujuan, misi dan visi organisasi yang tertuang dalam perumusan perencanaan strategis suatu organisasi. Kinerja dari suatu pemerintah daerah merupakan cerminan kualitas proses atau keberhasilan kegiatan/program yang telah dilakukan untuk mencapai tujuan-tujuan pembangunan yang diwujudkan dalam bentuk hasil berupa peningkatan pelayanan kepada masyarakat.

Kinerja pemerintah daerah memiliki arti yang sangat penting bukan saja bagi masyarakat selaku pemilik kedaulatan, dan para donator selaku penyumbang dana, tetapi juga penting bagi Pemerintah Daerah sendiri selaku Eksekutif, terlebih-lebih bagi DPRD yang secara fungsional memiliki tanggungjawab atas pelaksanaan fungsi legislasi, fungsi anggaran dan fungsi pengawasan.

\subsection{Pengelolaan Keuangan Daerah}

Menurut Peraturan Pemerintah Nomor 58 tahun 2005 tentang pengelolaan keuangan daerah pasal 1 ayat 5 menjelaskan bahwa keuangan daerah adalah segala hak dan kewajiban daerah dalam rangka penyelenggaraan pemerintah daerah yang dapat dinilai dengan uang termasuk didalamnya segala bentuk kekayaan yang berhubungan dengan hak dan kewajiban daerah tersebut,dalam kerangka anggaran pendapatan dan belanja daerah.

Menurut Permendagri 59 Tahun 2007 tentang Pedoman Pengelolaan Keuangan, menjelaskan bahwa pengelolaan keuangan daerah adalah keseluruhan kegiatan yang meliputi perencanaan, pelaksanaan, penatausahaan, pelaporan, pertanggungjawaban dan pengawasan keuangan daerah.

Perubahan dalam pengelolan keuangan daerah harus tetap berpegang pada prinsip-prinsip pengelolaan keuangan daerah (anggaran) yang baik.Prinsip -prinsip pengelolaan keuangan yang diperlukan untuk mengontrol kebijakan keuangan daerah meliputi : akuntabilitas, value for money, kejujuran dalam pengelolaan keuangan public, transparansi, dan pengendalian.

\subsection{Sistem Akuntansi Keuangan Daerah}

Menurut Abdul (2007: 42) Defenisi dari Akuntansi Keuangan daerah adalah proses pengidentifikasian, pengukuran, pencatatan, dan pelaporan transaksi ekonomi (keuangan) dari entitas pemerintah daerah (kabupaten, kota, atau provinsi) yang dijadikan sebagai informasi dalam rangka pengambilan keputusan ekonomi yang diperlukan oleh pihak-pihak eksternal entitas entitas pemerintah daerah (kabupaten, kota, atau provinsi). Prosedur Sistem Akuntansi Keuangan Daerah (SAKD) menurut Kepmendagri No. 29 Tahun 2002, meliputi: pencatatan, penggolongan dan pengikhtisaran, dan pelaporan.

Laporan keuangan disusun untuk menyediakan informasi yang dilakukan oleh suatu entitas selama satu periode pelaporan.Laporan keuangan tersebut oleh bagian keuangan akan dilaporkan kepada pihak-pihak yang memerlukannya.Pihak-pihak yang memerlukannya antara lain : Dewan Perwakilan Rakyat Daerah (DPRD); Badan Pengawas Keuangan; Investor; Kreditor; dan Donatur; Analisis dan Ekonomi dan Pemerhati Pemerintah Daerah; Rakyat; Pemerintah Daerah lain dan Pemerintah Pusat yang semuanya ada dalam lingkungan akuntansi keuangan daerah.

\subsection{Penelitian Terdahulu}

Penelitian terdahulu oleh (Hidayat, 2015), yang berjudul "Pengaruh Pengelolaan Keuangan Daerah dan Sistem Akuntansi Keuangan Daerah Terhadap Kinerja Pemerintah Daerah, berlokasi SKPD Kab. Padang Pariaman, dengan menggunakan metode penelitian Primer, analisis yang digunakan regresi berganda, dengan bantuan SPSS versi 16. Dan hasil penelitin menunjukan bahwa 
(1) Pengelolaan Keuangan daerah berpengaruh signifikan positif terhadap kinerja pemerintah daerah,

(2) Sistem keuangan daerah berpengaruh signifikan terhadap kinerja pemerintah daerah.

Peniliti terdahulu Primadona (2010) yang berjudul "Pengaruh Pengawasan Intern dan Pengelolaan Keuangan Daerah Terhadap Kinerja Pemerintah Daerah". Hasil penelitian ini menunjukan terdapat pengaruh secara simultan dari pengawasan intern dan pengelolaan keuangan daerah secara bersama-sama memberikan pengaruh yang signifikan terhadap kinerja pemerintah daerah.

Peneliti (Lintong \& Saerang, 2015), yang berjudul "Pengaruh Implementasi Sistem Akuntansi, Pengelolaan Keuangan Daerah Terhadap Fungsi Pengawasan dan Kinerja Pemerintah Daerah". Hasil penelitian ini menunjukan bahwa implementasi sistem akuntansi pemerintah dan implementasi keuangan daerah berpengaruh terhadap fungsi pengawasan intern.

Peneliti (Lia, 2009) yang berjudul "Pengaruh Pengawasan Intern dan Pelaksanaan Sistem Akuntansi Keuangan Daerah Terhadap Kinerja Pemerintah Daerah”. Hasil penelitian ini menunjukan pengawasan intern dan pelaksaan sistem akuntansi keuangan daerah mempunyai hubungan yang sangat kuat. Artinya pengawasan intern yang dilaksanakan efektif dan kontinyu mempengaruhi pelaksanaan sistem akuntansi keuangan daerah yang diterapkan akan lebih baik dan sebaliknya pelaksanaan sistem akuntansi keuangan daerah yang telah diterapkan dengan baik pada prinsipnya mempengaruhi pengawasan intern,karena pengawasan intern yang dilaksanakan.

\subsection{Pengembangan Hipotesis}

\subsubsection{Pengaruh Pengelolaan Keuangan Daerah Terhadap Kinerja Pemerintah Daerah}

Pengelolaan keuangan daerah yang berorientasi pada kinerja menunjukan adanya akuntabilitas kinerja yang terdapat keterkaitan antara sasaran strategis yang ingin dicapai dengan jumlah dana yang dialokasikan maka dapat diasumsikan bahwa pengelolaan keuangan daerah yang baik mempunyai pengaruh terhadap kinerja satu instansi atau organisasi. Hasil penelitian terdahulu yang dilakukan oleh Almanda (2014), yang meniliti tentang pengawasan intern dan pengelolaan keuangan daerah terhadap kinerja pemerintah daerah. Hasil penelitian ini menunjukan pengaruh yang signifikan terhadap kinerja pemerintah daerah.

\section{H1 : Pengelolaan Keuangan Daerah berpengaruh Terhadap Kinerja Pemerintah Daerah}

\subsubsection{Pengaruh Akuntansi Keuangan Daerah Terhadap Kinerja Pemerintah Daerah}

(PP Nomor 58, 2005) pasal 134 tentang Pengelolaan Keuangan Daerah disebutkan bahwa dalam rangka meningkatkan kinerja, transparasi dan akuntabilitas pengelolaan keuangan daerah, perlu dirancang suatu sistem yang mengatur proses pengklasifikasian, pengukuran dan pengungkapan seluruh transaksi keuangan yang disebut dengan Sistem Akuntansi Keuangan Daerah. Hasil penelitian terdahulu yang dilakukan oleh (Lia, 2009), menguji pengaruh pengawasan intern dan pelaksanaan system akuntansi keuangan daera terhadap kinerja pemerintah daerah. Hasil penelitian ini menunjukan bahwa pengawasan intern dan sistem akuntansi keuangan daerah berpengaruh signifikan terhadap kinerja pemerintah daerah,

H2 : Sistem Akuntansi Keuangan Daerah berpengaruh Terhadap Kinerja Pemerintah Daerah

\subsection{Model Penelitian}

Dari paparan diatas maka judul Pengaruh Pengelolaan Keuangan Daerah dan Sistem Akuntansi Keuangan Daerah Terhadap Kinerja Pemerintah Daerah dalam model penelitian : 


\section{Gambar 1}

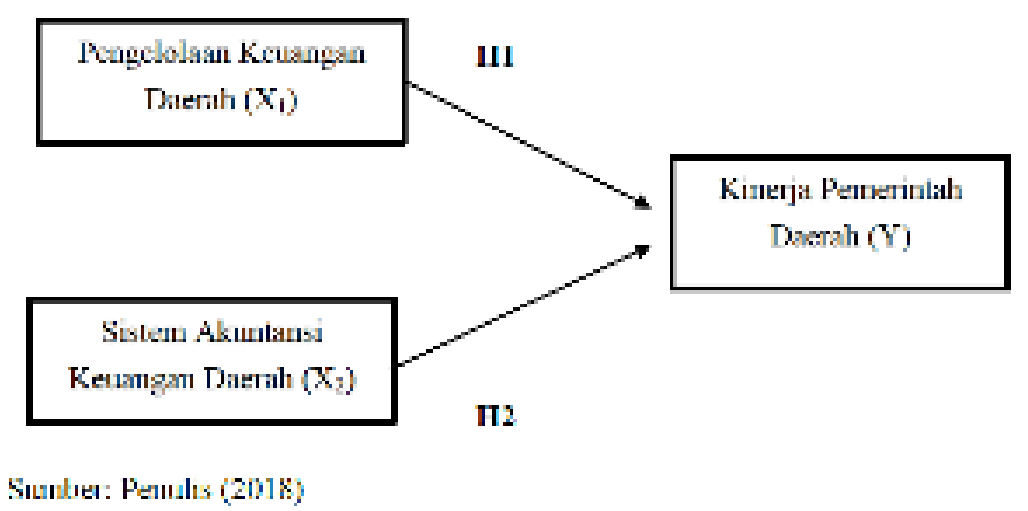

\section{METODE PENELITIAN}

\subsection{Jenis Penelitian}

Penelitian ini tergolong penelitian kausal merupakan penelitian hubungan yang bersifat sebab akibat untuk mencari hubungan antara satu variabel dengan variabel lainnya, hubungan variabel dalam penelitian ini ialah variabel independen Pengelolaan Keuangan Daerah dan Sistem Akuntansi Keuangan Daerah terhadap Variabel Dependen Kinerja Pemerintah Daerah.

\subsection{Populasi dan Sampel Penelitian}

Populasi dalam penelitian ini adalah staf bagian keuangan pada Organisasi Perangkat Daerah (ODP) Kota Jayapura.Teknik pengambilan sampel dalam penelitian ini menggunakan teknik pengumpulan data secara purposive sampling,yaitu untuk memperoleh sampel yng memenuhi kriteria tertentu, dan diperoleh kriteria aman terkendali. Kriteria sampel yang dimaksud ada kriteria, yaitu: Staf bagian keuangan.

\subsection{Jenis dan Sumber Data}

Jenis Data dalam penelitian ini adalah data kuantitatif,berupa nilai atau skor atas jawaban yang diberikan oleh responden terhadap pertanyaan yang ada dalam koesioner. Sumber Data penelitian ini menggunakan data primer. Data primer adalah data yang diperoleh dengan survei lapangan yang menggunakan semua metode pengumpulan data original.

Sumber data dalam penelitian ini menggunakan sumber data primer. Menurut Sugiyono (2010). Sumber data primer adalah sumber data yang langsung memberikan data kepada pengumpul data.Sumber data primer penelitian ini adalah Kepala Bagian Keuangan dan staf keuangan yang terdapat dalam OPD Kota Jayapura.

\subsection{Teknik Pengumpulan Data}

Pengumpulan data dilakukan dengan menggunakan kuesioner .Kuesioner diantarkan langsung ke OPD responden dan untuk pengembaliannya akan dijemput sendiri oleh peneliti pada waktu yang telah ditentukan dan kuesioner harus diisi sendiri oleh pimpinan OPD Kota Jayapura. Skala pengukuran yang digunakan dalam penelitian ini adalah skala Likert,sebagaimana yang dinyatakan oleh (Ghozali, 2001) skala yang sering dipakai dalam penyusunan kuesioner adalah ordinal dalam bentuk skala likert yang berisi lima tingkat profesi jawaban. Pengukuran variabel dalam penelitian ini menggunakan skala likert dengan lima alternatif jawaban masing-masing diberi skor yaitu 
:(1.)Sangat Tidak Setuju (STS),(2.) Tidak Setuju (TS), (3.)Netral (N),(4) Setuju (S),(5) Sangat Setuju (SS).

\subsection{Variabel Penelitian dan Definisi Operasional \\ 3.5.1 Variabel Terikat (dependent variable)}

Variabel terikat (dependent variable) adalah variabel yang menjadi perhatian utama dalam sebuah pengamatan Variabel dependen dalam penelitian ini adalah Kinerja Pemerintah Daerah.

Kinerja Pemerintah Daerah adalah Gambaran mengenai tingkat pencapaian pelaksanaan suatu kegiatan/ program/ kebijaksanaan dalam mewujudkan sasaran, tujuan, misi, dan visi organisasi yang tertuang dalam perumusan skema stategis (strategic planning) suatu organisasi. Secara umum dapat dikatakan juga bahwa kinerja merupakan prestasi yang dapat dicapai organisasi dalam periode tertentu dalam penelitian ini instrument diadopsi oleh (Hidayat,2015) dengan 11 butir pertanyaan.

\subsubsection{Variabel Bebas (independent variable)}

Variabel independen (variabel bebas) adalah variabel yang dapat mempengaruhi perubahan dalam variabel dependen dan mempunyai pengaruh positif ataupun negatif bagi variabel dependen nantinya. Variabel bebas (independent variable) dalam penelitian ini adalah Pengelolaaan Keuangan daerah (X1), dan Sistem Akuntansi Keuangan daerah (X2).

\section{a. Pengelolaan Keuangan Daerah}

Pengelolaan keuangan daerah adalah keseluruhan kegiatan yang meliputi perencanaan, pelaksanaan, penatausahaan, pelaporan, pertanggungjawaban dan pengawasan keuangan daerah.

Pengelolaan keuangan menurut (PP Nomor 58, 2005) adalah keseluruhan kegiatan meliputi perencanaan, pelaporan, pertanggungjawaban dan pengawasan keuangan daerah.Untik melihat baik tidaknya pengelolaan keuangan daerah sutu pemerintahan dapat dilihat dari hasil Laporan Hasil Pemeriksaan (LHP) Badan Pemeriksaan Keuangan (BPK) Republik Indonesia.

Pengelolaan Keuangan Daerah dilaksanakan oleh pemegang kekuasaan pengelolaan keuangan daerah. Kepala daerah selaku kepala pemerintahan daerah adalah pemegang kekuasaan pengelolaan keuangan daerah dan mewakili pemerintah daerah dalam kepemilikan kekayaan daerah yang dipisahkan. Kepala daerah perlu menetapkan pejabat-pejabat tertentu dan para bendahara untuk melaksanakan pengelolaan keuangan daerah. Dalam penelitian ini instrument yang diadopsi oleh Rahmat Hidayat (2014) dengan 9 butir pertanyaan.

\section{b. Sistem Akuntansi Keuangan Daerah}

Sistem akuntansi keuangan daerah merupakan serangkaian prosedur yang saling berhubungan yang disusun sesuai dengan suatu skema yang menyeluruh yang ditinjau untuk menghasilkan informasi dalam bentuk laporan keuangan yang akan digunakan oleh pihak intern dan pihak ekstern pemerintah daerah untuk mengambil keputusan ekonomi yang memiliki konsentrasi Akuntansi Sektor Publik.

Sistem akuntansi keuangan daerah adalah proses pengidentifikasian, pengukuran, pencatatan, dan pelaporan transaksi ekonomi (keuangan) dari entitas pemerintah daerah (kabupaten, kota, atau provinsi) yang dijadikan sebagai informasi dalam rangka pengambilan keputusan ekonomi yang diperlukan oleh pihak-pihak eksternal entitas-entitas pemerintah daerah (kabupaten, kota, atau provinsi). . 


\subsection{Metode Analisis Data}

Alat uji yang digunakan adalah Regresi Linear Berganda. Analisis regresi linear berganda digunakan untuk menguji pengelolaan keuangan daerah dan sistem akuntansi keuangan daerah terhadap kinerja pemerintah daerah di lingkungan OPD kota Jayapura,metode ini menggunakan bantua program SPSS. Uji digunakan karena penelitian ini menggunakan lebih dari satu variabel bebas dan satu variabel terikat. Untuk mengetahui pegaruh variabel independen terhadap variabel dependen digunakan model regresi berganda dengan persamaan sebagai berikut:

$\mathbf{Y}=\boldsymbol{\alpha}+\boldsymbol{\beta} 1 \mathrm{X} 1+\boldsymbol{\beta} 2 \mathrm{X} 2+\varepsilon$

Keterangan :

$\mathrm{Y}=$ Kinerja Pemerintah Daerah

$\beta \mathrm{x}=$ Koefisien regresi dari variable independen

$\mathrm{X} 1=$ Pengelolaan Keuangan Daerah

$\mathrm{X} 2=$ Sistem Akuntansi Keuangan Daerah

$\alpha=$ constant

$\varepsilon=$ Error

\section{HASIL PENELITIAN DAN PEMBAHASAN}

\subsection{Gambaran Umum Responden}

Penelitian ini bertujuan untuk mengetahui Pengaruh Pengelolaan Keuangan Daerah dan Sistem Akuntansi Keuangan Daerah Terhadap Kinerja Pemerintah Daerah di Kota Jayapura.Penelitian ini dilakukan pada Organisasi Perangkat Daerah Kota Jayapura.

Organisasi Perangkat Daerah dijayapura yang diteliti sebanyak 34, yakni yang terdiri dari 6 Badan,18 Dinas, 7 Bagian dan ditambah 3 OPD lagi di kota jayapura.

Data Kuesioner yang disebarkan 102 Kuesioner,yang kembali 70 kuesioner.Sedangkan Kuesioner yang tidak kembali sebanyak 32 kuesioner,maka jumlah kuesioner yang dapat dianalisis adalah sebanyak 70 kuesioner,dengan tingkat pengembalian sebesar (70\%).

\subsection{Statistik Deskriptif}

Statistik deskriptif mempunyai tujuan untuk memberikan gambaran variabel-variabel penelitian.Hasil analisis deskriptif dengan menggunakan program SPSS 16 dapat dilihat dari tabel 1 berikut ini:

\section{Tabel 1}

\section{Statistik Deskriptif}

\begin{tabular}{|c|c|c|c|c|c|}
\hline & $\mathrm{N}$ & Minimum & Maximum & Mean & $\begin{array}{l}\text { Std. } \\
\text { Deviation }\end{array}$ \\
\hline $\begin{array}{l}\text { Pengelolaan Keuangan } \\
\text { Daerah }\end{array}$ & 70 & 7.00 & 35.00 & 23.5571 & 6.73867 \\
\hline $\begin{array}{l}\text { Sistem Akuntansi } \\
\text { Keuangan Daerah }\end{array}$ & 70 & 14.00 & 35.00 & 29.2286 & 3.95325 \\
\hline $\begin{array}{l}\text { Kineria Pemerintah } \\
\text { Daerah } \\
\text { Valid N (listwise) }\end{array}$ & 70 & 30.00 & 50.00 & 42.9000 & 4.61927 \\
\hline
\end{tabular}


Variabel Pengelolaan keuangan daerah mempunyai bobot jawaban antara nilai minimum sebesar 7,00 dan nilai maximum 35,00 dengan nilai rata-rata (mean)23,5571 dan standar deviasi 6,73867 , Sedangkan variabel Sistem Keuangan Daerah mempunyai bobot jawaban antara nilai minimum sebesar 14,00 dan nilai maximum 35,00 dengan nilai rata-rata (mean) S29,2286 dan standar deviasi 3,95325. Variabel Kinerja Pemerintah Daerah mempunyai bobot jawaban anatara nilai minimum sebesar 30,00 dan nilai maximum 50,00 dengan nilai rata-rata (mean) 42,9000 dan standar deviasi 4,61927. Jadi Pengelolaan Keuangan Daerah dan Sistem Keuangan Daerah Terhadap Kinerja Pemerintah Daerah dengan tingkat relative tinggi, dan nilai standar deviasi lebih kecil dari nilai mean yang menunjukkan data tersebut baik

\subsection{Pengujian Hipotesis}

Alat statistik yang digunakan untuk menguji hipotesis adalah regresi berganda (multi regression). Hal ini sesuai dengan rumusan masalah, tujuan serta hipotesis-hipotesis yang dilakukan dalam penelitian ini. Regresi berganda menghubungkan satu veriabel dependen dengan beberapa variabel independen dalam suatu modal prediktif tunggal.

Model regresi berganda yang digunakan dalam penelitian ini disajikan dalam persamaan berikut ini :

$\mathbf{Y}=\boldsymbol{\alpha}+\boldsymbol{\beta} 1 \mathrm{X} 1+\boldsymbol{\beta} 2 \mathrm{X} 2+\varepsilon$

Keterangan :

$\mathrm{Y}=$ Kinerja Pemerintah Daerah

$\beta \mathrm{x}=$ Koefisien regresi dari variable independen

$\mathrm{X} 1=$ Pengelolaan Keuangan Daerah

X2 $=$ Sistem Akuntansi Keuangan Daerah

$\alpha=$ constant

$\varepsilon=$ Error

Pengaruh variabel independen terhadap variabel dependen diuji pada taraf signifikansi 5\%. Kriteria pengambilan keputusan dalam melakukan penerimaan dan penolakan setiap hipotesis adalah dengan membandingkan nilai thitung dengan $t$ tabel untuk masing-masing koefisien regresi. Apabila thitung lebih kecil dari t tabel, maka hipotesis nol (Ho) tidak dapat ditolak. Dan apabila t hitung lebih besar dari nilai t tabel, maka Ho ditolak. Selain kriteria perbandingan $t$ hitung dengan $t$ tabel, juga digunakan kriteria nilai $\mathrm{p}$ value (kekuatan koefisien regresi dalam menolak Ho). Jika $\mathrm{p}$ value $=0,05$ maka Ho ditolak dan apabila $\mathrm{p}$ value $>0,05$ maka Ho tidak dapat ditolak.

\subsubsection{Analisis Regresi Berganda}

Alat uji yang digunakan adalah Regresi Linear Berganda. Analisis regresi linear berganda digunakan untuk menguji pengelolaan keuangan daerah dan sistem akuntansi keuangan daerah terhadap kinerja pemerintah daerah di lingkungan OPD kota Jayapura,metode ini menggunakan bantua program SPSS. Uji digunakan karena penelitian ini menggunakan lebih dari satu variabel bebas dan satu variabel terikat. Berdasarkan perhitungan diperoleh hasil regresi sebagai berikut :

Tabel 2

Hasil Uji Analsis Regresi Berganda 


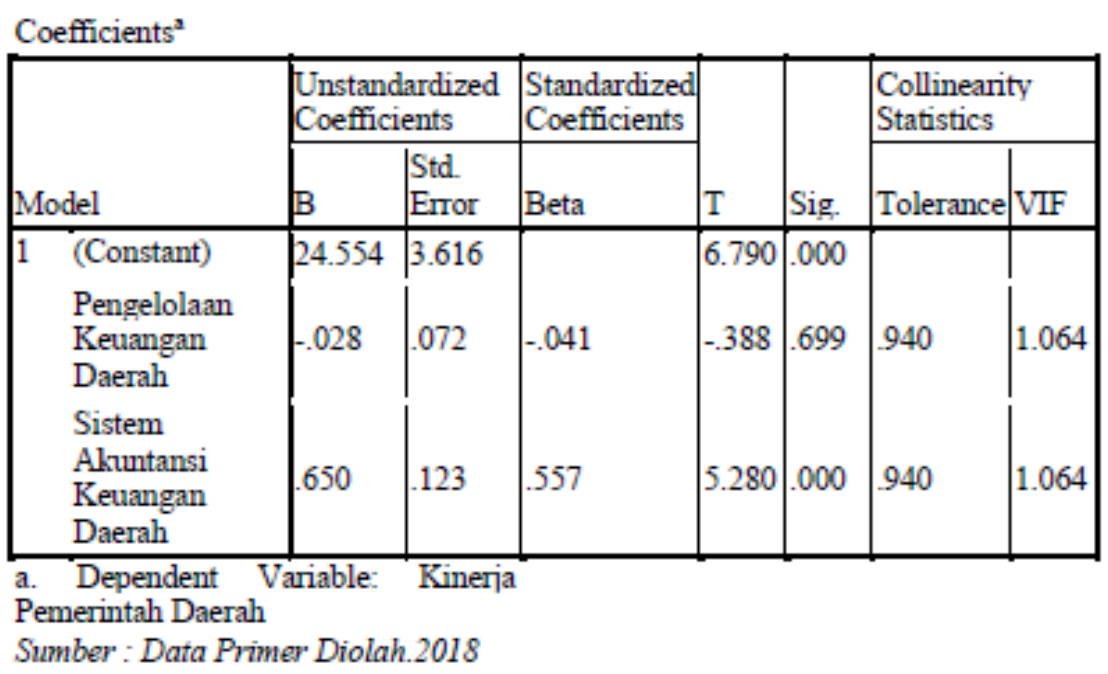

Berdasarkan tabel diatas dapat dianalisis model estimasi sebagai berikut :

$$
\mathbf{Y}=\mathbf{2 4 . 5 5 4 - 0 , 0 2 8 \times 1 + 0 , 6 5 0 \times 2 + €}
$$

Dari persamaan diatas dapat dijelaskan bahwa ;

1. Nilai konstan sebesar 24,554 mengindikasikan bahwa jika variabel independen yaitu Pengelolaan Keuangan Daerah dan Sistem Akuntansi Keuangan Daerah dan Kinerja Pemerintah Daerah adalah nol maka kinerja pemerintah daerah sebesar konstanta 24,554.

2. Koefisien Pengelolaan Keuangan Daerah sebesar -0,028 mengindikasikan setiap peningkatan satu kesatuan pengelolaan keuangan daerah maka akan menurunkan kinerja pemerintah daerah sebesar 0,028 dengan asumsi variabel lain konstan.

3. Koefisien Sistem Akuntansi keuangan daerah sebesar 0,650 mengindikasikan bahwa setiap peningkatan satu kesatuan sistem akuntansi keuangan daerah,maka akan meningkatkan kinerja pemerintah daerah sebesar 0,650 dengan asumsi variabeel lain konstan.

\subsubsection{Uji Koefisien Determinasi $\left(R^{2}\right)$}

Uji determinasi adalah uji yang digunakan untuk mengetahui besaran dalam persen pengaruh variabel independen secara keseluruhan terhadap variable dependen (Ghozali, 2005). Nilai koefisien determinasi dapat dilihat pada table berikut:

\section{Tabel 3}

Hasil Uji Koefisien Determinasi

Model Summary ${ }^{b}$

\begin{tabular}{|c|c|c|c|c|}
\hline Model & R & R Square & Adjusted R Square & $\begin{array}{c}\text { Std. Error of the } \\
\text { Estimate }\end{array}$ \\
\hline 1 & $.548^{\mathrm{a}}$ & .300 & .279 & 3.92137 \\
\hline
\end{tabular}

a. Predictors: (Constant), Sistem Akuntansi Keuangan Daerah,

\section{Pengelolaan Keuangan Daerah}

\section{b. Dependent Variable: Kinerja Pemerintah Daerah}

\section{Sumber : Data Primer Diolah,2018}

Nilai adjusted R Square menunjukan 0,279. Hal ini mengindikasikan bahwa kontribusi variabel bebas yaitu pengelolaan keuangan daerah dan sistem akuntansi keuangan daerah terhadap variabel terikat yaitu kinerja pemerintah daerah daerah 27,9\% sedangkan $72,1 \%$ ditentukan faktor lain. 


\subsubsection{Uji T}

Uji t (uji koefisien regresi secara parsial) digunakan untuk mengetahui apakah secara parsial pengelolaan keuangan daerah dan sistem akuntansi keuangan daerah berpengaruh signifikan atau tidak terhadap tindakan kinerja pemerintah daerah. Hal ini berdasarkan perbandingan nilai thitung masing-masing koefisien dengan ttabel, dengan tingkat signifikansi 5\%.

\section{Tabel 4}

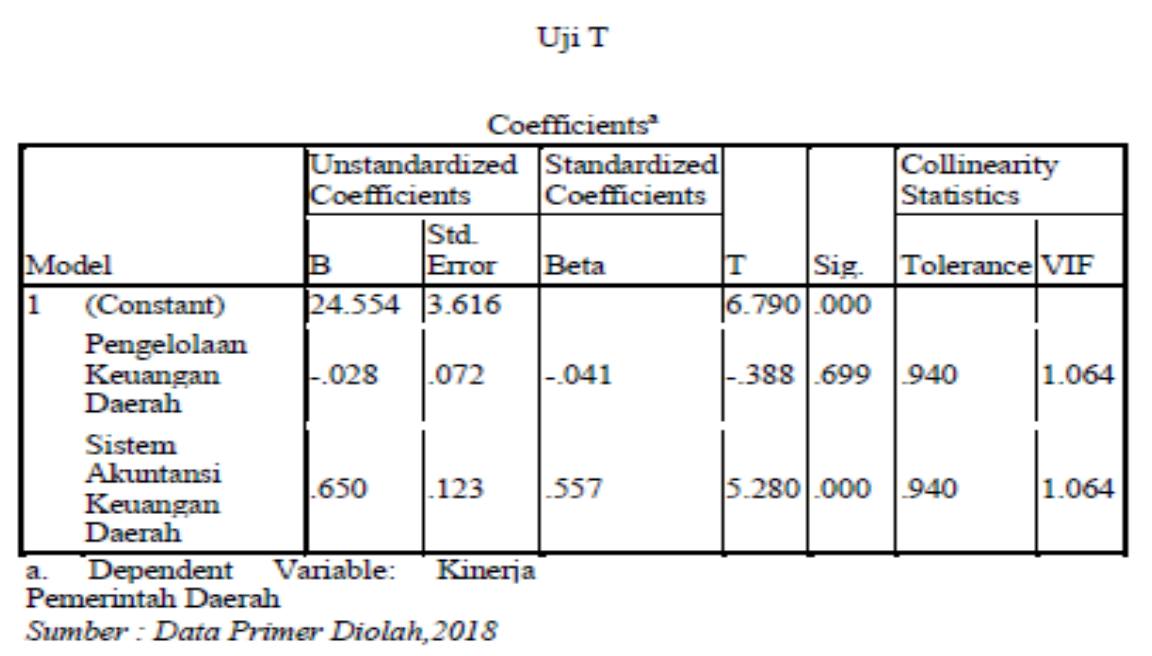

Berdasarkan tabel 4 diatas dapata disimpulkan hasil hipotesis 1 dan hipotesis 2 sebagai berikut :

\section{Pengelolaan Keuangan Daerah (H1)}

Variabel pengelolaan keuangan daerah (X1) nilai t hitung 0,388 $<\mathrm{t}$ tabel 1,994 dan nilai signifikan 0.699 > 0,05. Dari hasil uji t pada variabel ini maka dapat dikatakan pengaruh pengelolaan keuangan daerah terhadap kinerja pemerintah daerah tidak berpengaruh secara signifikan,dengan demikian pada hipotesis 1 di tolak.

\section{Sistem Akuntansi Keuangan Daerah (H2)}

Variabel sistem keuangan daerah (X2) nilai t hitung 5,280 > t tabel 1,994 dan nilai signifikan $0,00<0,005$.Dari hasil uji t pada variabel ini dapat dikatakan pengaruh sistem akuntansi keuangan daerah terhadap kinerja pemerintah daerah berpengaruh secara signifikan, dengan demikian hipotesis 2 diterima.

\subsection{Pembahasan}

Berdasarkan hasil analisis regresi dan pengujian hipotesis yng dilakukan, peneliti menemukan ada perbedaan hasil penelitian ini dengan penelitian seebelumnyat (Hidayat, 2015) di kabupaten Padang Pariaman. Variabel pengelolaan keuangan daerah berpengaruh negatif atau tidak berpengaruh terhadap kinerja pemerintah daerah, sedangkan variabel sistem akuntansi keuangan daerah berpengaruh positif atau berpengaruh terhadap kinerja pemerintah daerah.

\subsubsection{Pengaruh Pengelolaan Keuangan Daerah Terhadap Kinerja Pemerintah Daerah}

Dari hasil penelitian ini nilai uji t dari variabel ini 0,0388 dan nilai signifikansinya 0,699 dimana nilai $\mathrm{t}$ dari penelitian sangat kecil dibandingan dengan nilai $\mathrm{R}$ tabel dimana $\mathrm{t}$ hitung $0,388<\mathrm{t}$ tabel 1,994 sedangkan nilai signifikan $0,699>0,05$. Yang artinya analisis statistik dalam penelitian ini ditemukan bahwa hipotesis pertama (H1) yaitu pengelolaan keuangan daerah tidak berpengaruh secara signifikan terhadap kinerja pemerintah daerah, dapat dikatakan pula semakin menurut 
pengaruh pengelolaan keuangan daerah berarti menurunnya kinerja pemerintah daerah.Dengan demikian pada hipotesis pertama di tolak.

Hasil penelitian ini konsisten dengan penelitian yang dilakukan oleh (Yusmalizar, 2014)) yang menyatakan bahwa tidak adanya pengaruh signifikan tersebut dapat dikarenakan berbagai hal diantaranya belum maksimalnya pemanfaatan sistem anggaran bagi ASN, yang dapat menjamin bahwa penhgelolaan keuangan daerah dilakukan konsisten sesuai peraturan perundang-undangan yang berlaku serta pengeliuaran keuangan daerah yang dilakukan belum berorientasi pada pencapaian visi,misi,tujuan dan hasil (manfaat) yang dicapai.

Searah dengan peneliti sebelumnya oleh (Yusmalizar, 2014) tentang Pengaruh pengawasan intern dan pengelolaan keuangan daerah terhadap kinerja pemerintah daerah yang dimana variabel pengelolaan keuangan daerah terhadap kinerja pemerintah daerah berpengaruh signifikan negativ.Yang mempunyai kesamaan dengan penelitian ini jjdimana variabel pengelolaan keuangan daerah berpengaruh negatif terhadap kinerja pemerintah daerah.

\subsubsection{Pengaruh Sistem Akuntansi Keuangan Daerah Terhadap Kinerja Pemerintah Daerah}

Berdasarkan hasil penelitian didapat nilai t dari variabel ini adalah sebesar 5,280 dan nilai ini leboh besar dari nilai $\mathrm{R}$ tabel yakni sebesar 1,994. Dan nilai signifikan sebesar 0,00, dimana nilai $\mathrm{t}$ hitung 5,280 > 1,994 nilai $\mathrm{R}$ tabelnya.Yang artinya analisis statistik dalam penelitian ini ditemukan bahwa hipotesis kedua (H2) yaitu sistem akuntansi keuangan daerah berpengaruh secara signifikan terhadap kinerja pemerintah daerah.Dapat dikatakan pula semakin baik pengaruh sistem akuntansi keuangan daerah makan semakin baik pula kinerja pemerintah daerah, dengan demikian Hipotesis kedua dapat diterima.

Hasil penelitian ini sesuai dengan teori yang dikemukakan (Primadona, 2004) yang mana kinerja pemerintah daerah akan tercapai dengan dilaksanakannya sistem akuntansi keuangan daerah, dan sistem akuntansi keuangan daerah dapat menimbulkan dukungan yang kuat terhadap kinerja pemerintah yang dicapai.

Sistem Akuntansi Keuangan Daerah mempunyai arti yang sangat penting dalam rangka pelaksanaan pemerintahan, oleh karena itu sistem akuntansi keuangan daerah diupayakan untuk terus berjalan untuk meningkatkan kinerja pemerintah daerah. Pemerintah daerah sebagai pihak yang diserahi tugas menjalankan roda pemerintahan, pembangunan, dan layanan sosial masyarakat bertanggungjawab memberikan pelayanan kepada masyarakat.

Searah dengan penelitian sebelumnya oleh (Hidayat, 2015) yang meneliti tentang Pengaruh pengelolaan keuangan daerah dan sistem akuntansi keuangan daerah terhadap kinerja pemerintah daerah yang menunjukan variabel sistem akuntansi keuangan daerah berpengaruh signifikan positif terhadap kinerja pemerintah daerah.

\section{PENUTUP}

\subsection{Kesimpulan}

Berdasarkan hasil pengujian hipotesis dan mengacu pada perumusan serta tujuan dari penelitian ini, maka dapat ditarik kesimpulan-kesimpulan sebagai berikut :

1. Nilai thitung dari variabel ini lebih kecil dibanding nilai $r$ tabel yakin $0,388<1,994$ jika dilihat dari hasil uji t ini dapat dikatakan bahwa Hipotesis pertama pengelolaan keuangan daerah tidak berpengaruh secara signifikan terhadap kinerja pemeintah,yang berarti semakin menurunnya pengaruh pengelolaan keuangan daerah maka semakin menurun kinerja pemerintah daerah di lingkungan OPD Kota Jayapura.

2. Berdasarkan hasil penelitian ini nilai t lebih besar dari nilai $\mathrm{R}$ tabel yakni 5,280 > 1,994 dan dapat dikatakan bahwa hipotesis kedua sistem akuntansi keuangan daerah berpengaruh secara 
signifikan terhadap kinerja pemerintah daerah, yang berarti semakin baik sistem akuntansi keuangan daerah, maka baik juga kinerja pemerintah daerah di lingkungan OPD Kota Jayapura.

\subsection{Keterbatasan Penelitian}

Penelitian ini memiliki sejumlah keterbatasan yang perlu diperhatikan bagi peneliti selanjutnya, yaitu sebagai berikut:

1. Tidak dilakukanya metode wawancara dalam penelitian, mengingat kesibukan dari masing-masing responden sehingga jawaban responden belum tentu menggambarkan keadaan sebenarnya.

2. Penelitian ini hanya dilakukan di OPD sekota Jayapura saja, sehingga jawaban dari responden kurang variatif.

3. Penelitian ini hanya menggunakan 2 variabel independen yakni, Pengelolaan keuangan daerah dan Sistem akuntansi keuangan daerah sehingga kemungkinan ada variabel lain yang mempengaruhi kinerja pemerintah daerah seperti pengawasan intern.

4. Kuesioner variabel X1 pada peneliti kurang dimengeerti sehingga menjadi salah satu kelemahan peneliti.

\subsection{Saran}

Saran - saran yang dapat disampaikan oleh penulis sebagai hasil dari penelitian, pembahasan, ksesimpulan serta keterbatasan diatas. Harapan penulis dalam penelitian ini dapat membantu memberikan nilai lebih pada penelitian selanjutnya.

1. Untuk penelitian selanjutnya perlu dilakukan wawancara yang dapat membantu mengendalikan jawaban tiap responden.

2. Untuk penelitian selanjutnya agar diperluas dengan menambahkan Kota/Kabupaten sekitar Jayapura seperti Kabupaten Keerom sehingga mendapat hasil yang berbeda. 


\section{DAFTAR PUSTAKA}

Dewi, \& Harimurti, F. (2017). Pengaruh Pengawasan Internal, Sistem Akuntansi Keuangan Daerah Pengelolaan Keuangan Daerah Terhadap Kinerja Keuangan Daerah Pemerintah Kabupaten Karanganyar (Survey pada DPPKAD Kabupaten Karanganyar) Oleh. Eksporasi, XXIX(2).

Hidayat, R. (2015). Pengaruh pengelolaan keuangan daerah dan sistem akuntansi keuangan daerah terhadap kinerja pemerintah daerah. Ejournal.Unp.Ac.Id, 1-27. https://doi.org/10.1017/CBO9781107415324.004

Irfan, M., Santoso, B., \& Effendi, L. (2016). Pengaruh Partisipasi Anggaran terhadap Senjangan Anggaran dengan Asimetri Informasi, Penekanan Anggaran dan Komitmen Organisasional sebagai Variabel Pemoderasi. Jurnal Akuntansi Dan Investasi, 17(2), 158-175. https://doi.org/10.18196/jai.2016.0052.158-175

Jensen, C., \& Meckling, H. (1976). Theory of the Firm : Managerial Behavior, Agency Costs and Ownership Structure. Journal of Financial Economics, 3, 305-360.

Lia, wawan dan. (2009). Pengaruh Pengawasan Intern dan Pelaksanaan Sistem Akuntansi Keuangan Daerah Terhadap Kinerja Pemerintah Daerah ( Survei pada Satuan Kerja Perangkat Daerah Kota Tasikmalaya ). Jurnal Akuntansi FE Unsil, 4(1). https://doi.org/1907-9958

Lintong, D. N., \& Saerang, D. P. E. S. (2015). Pengaruh Implementasi Sistem Akuntansi, Pengelolaan Keuangan Daerah Dan Pengawasan Internal Terhadap Kinerja Pemerintah Kota Kotamobagu, 2(1), 37-48.

PP Nomor 58. (2005). Peraturan Pemerintah Republik Indonesia Nomor 58 Tahun 2005. Peraturan Pemerintah Republik Indonesia Nomor 58 Tahun 2005.

Primadona, A. (2004). "Pengaruh Pengawasan Intern dan Pengelolaan Keuangan Daerah Terhadap Kinerja Pemerintah Daerah“ (Penelitian Pada Pemerintah Kota Bandung).

Ratna, I., \& dkk. (2016). Pengaruh Pengelolaan Keuangan Daerah Terhadap Penerapan Sistem Akuntabilitas Kinerja Instansi Pemerintah Di Lingkungan Pemerintah Provinsi Riau. Peneltian Sosial Keagamaan, 19(1), 1-24. Retrieved from ejournal.uinsuska.ac.id/index.php/Kutubkhanah/article/download/2504/1585

Yuliana Dwi Jayanti. (2015). Pengaruh Good Governance,Pengelolaan Keuangan Daerah dan Sistem Akuntansi Keuangan Daerah Terhadap Kinerja Pemerintah Daerah, 1-15.

Yusmalizar. (2014). Pengaruh Pengawasan Intern dan pengelolaan keuangan daerah terhadap kinerja pemerintah daerah (Studi Empiris Pada SKPD Pemerintah Provinsi Sumatera Barat), 1-8. 